\title{
Exploring the Relationship between Chinese First Year University Students' Beliefs about Language Learning and Foreign Language Anxiety
}

\author{
Runhan Zhang \\ School of Foreign Studies, Central University of Finance and Economics \\ Beijing, P.R. China \\ E-mail: zhangrunhan_nora@hotmail.com
}

Received: 18-08-2013

doi:10.7575/aiac.ijalel.v.3n.1p.28
Accepted: 29-09-2013

Published: 01-01-2014

URL: http://dx.doi.org/10.7575/aiac.ijalel.v.3n.1p.28

\begin{abstract}
The aims of the study are to investigate what beliefs Chinese university first-year English majors have about language learning, whether they report anxiety about studying English, and whether there is a relationship between their beliefs and language anxiety. Two questionnaires were used in this study - Tanaka's beliefs questionnaire and Horwitz's Foreign Language Classroom Anxiety Scale. A series of statistical analyses were carried out on the responses. The results revealed that the Chinese university first-year English majors held four types of beliefs, namely Approach to Learning English, Self-efficacy and Confidence in English, Formal and Structured Learning, and Ease of Learning English. Comparing the means of all items in the beliefs questionnaire, it seemed that the respondents held a strong belief in the importance of learning vocabulary for them to speak English well. The respondents also reported some anxiety about learning English. However, it was interesting that the overall mean of their anxiety scores was lower than the means in previous studies. This study also found that there was no significant relationship between the participants' beliefs and their language anxiety, which echoed the results of Kunt's (1997) study, but two beliefs factors and several items were found to weakly correlate with the anxiety.
\end{abstract}

Keywords: Chinese first year students, language learner beliefs, foreign language anxiety, relationship

\section{Introduction}

Previous research suggests that learners' unrealistic beliefs about language learning may lead to anxiety (Horwitz, Horwitz \& Cope, 1986; Horwitz, 1988; Young, 1991) and at the same time anxiety can influence learner beliefs (Bandura, 1982). However, little empirical research has directly examined this relationship. In particular, no study has examined this relationship in China 'which has the largest number of EFL learners in the world' (Liu, 2006). Therefore, one purpose of the study is to describe beliefs about language learning and foreign language anxiety respectively among Chinese first-year university students majoring in English, who just began their university-level studies and where learning English was their most important task. The other purpose is to examine the relationship between these two constructs in this EFL context.

\subsection{Learner Beliefs about Language Learning}

There is as yet no consensus on the definition of learner beliefs. In applied linguistics, learner beliefs about language learning are generally defined as learners' ideas or opinions about various aspects of language learning (Horwitz, 1986; Truitt, 1995; Kunt, 1997). Tanaka (2004) discussed beliefs and learner beliefs in the framework of social psychology. From a social psychology perspective, beliefs are thought to be 'the associations or linkages that people establish between an object (e.g., English) and various attributes (e.g., difficult, an important language, should be learned by everyone)' (Tanaka, 2004, p.7). Icek Ajzen's theory of planned behaviour (Ajzen, 1985, 1988, 1991, 1996, 2002) proposes that 'individuals' beliefs are mainly formed by their direct experience with the belief object in a specific context, and are more or less affected by perceived social pressure or social norms' (Cited in Tanaka, 2004, p.22). Learners' beliefs about language learning could be also considered as social constructs and thus they are influenced by the social context of learning such as the general exposure of learners to the target language, the roles of the target language, and general perceptions about the value of the target language (Spolsky, 1989). Learner beliefs about language learning should be 'task-specific as well as context-specific' and they 'exist independently of their general epistemological beliefs (i.e., beliefs about the nature of knowledge and learning in general)' (Tanaka, 2004, p.23).

The classification of learner beliefs is also controversial among researchers of second language acquisition. Previous studies were conducted with different groups of learners and revealed a number of different categories of learner beliefs. Tanaka's (2004) review concluded there were three ways to identify the dimensions of learner beliefs: logicallyderived categories (e.g. Horwitz, 1987; Wen \& Johnson, 1997), focusing on similarities and differences in items and semantic coherence within a category; empirically-derived categories (e.g. Yang, 1992; Park, 1995; Truitt, 1995; Kunt, 1997), using statistical procedures, 
such as factor analysis; and inductively-derived categories (e.g., Wenden, 1986), based on qualitative data such as semistructured interviews, open questionnaires and diaries. Tanaka proposed a fourth way to generate belief categories based on a detailed observation of the categories shown in previous studies and an extensive review of the literature regarding learner beliefs. Adopting this fourth way, Tanaka (2004) proposed three types of beliefs which may exist among Japanese students: beliefs about analytic learning, which 'emphasise the explicit study of the target language as a linguistic system' (Tanaka, 2004, p.90); beliefs about experiential learning, which 'emphasise the importance of learning by using the target language for communicative purposes in authentic situations' (Tanaka, 2004, p.90); and affective states (beliefs about personal factors), which include self-efficacy, confidence, how they feel when using the language, how they evaluate their progress, and so on. Tanaka's (2004) way of categorising learner beliefs may be called deductively-derived categories. Tanaka developed a 27-item questionnaire to explore Japanese students' beliefs about language learning both in Japan and in a study-abroad context (New Zealand). The following table summarises some of the categories demonstrated by previous studies conducted in Asian context, in which English is learned as a foreign language.

Table 1. Categories of Learner Beliefs about Language Learning from Previous Studies

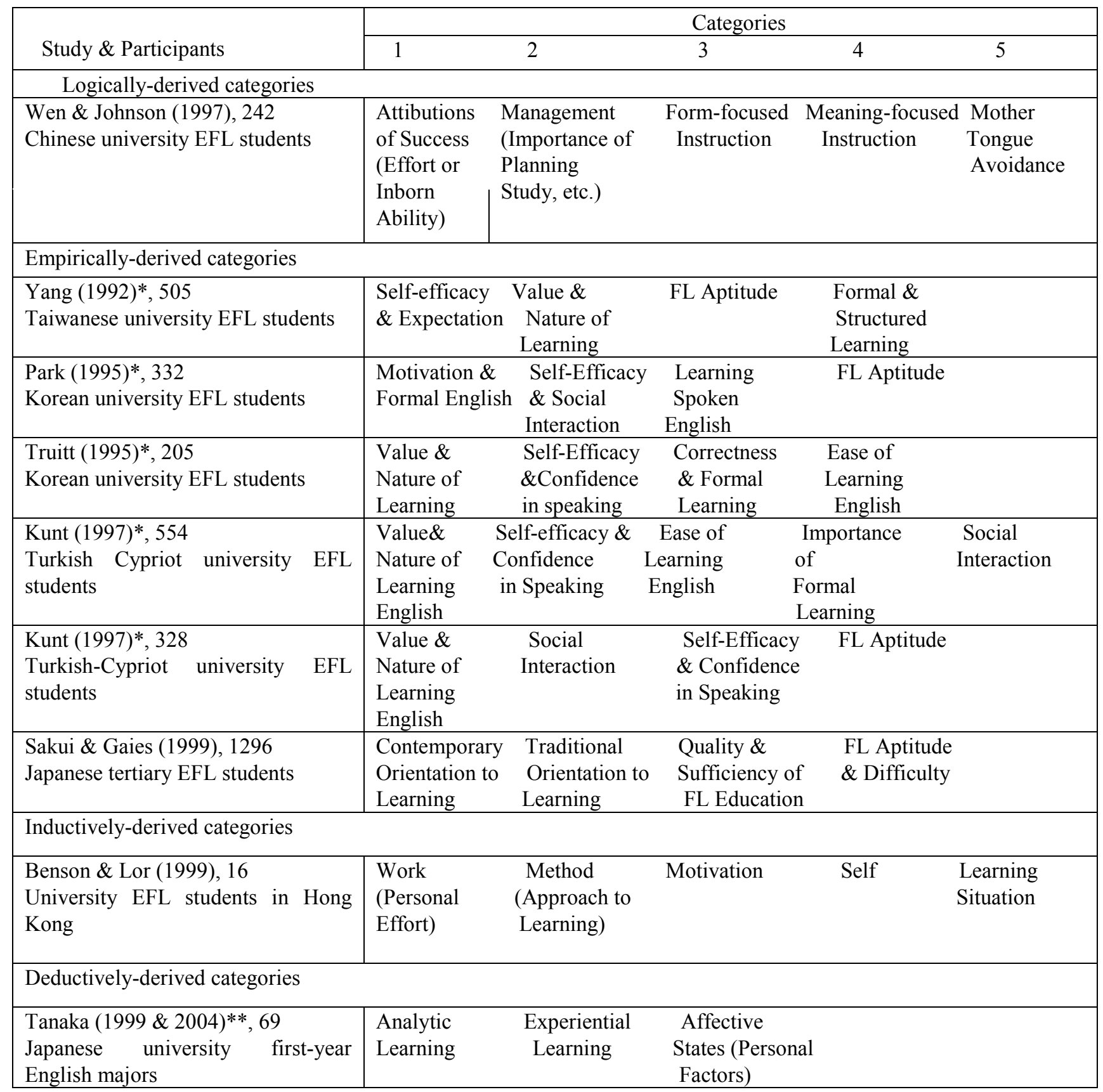

Note. Source: Tanaka (2004), p.45

EFL: English as a foreign language

FL: Foreign Language

* Used BALLI (Beliefs About Language Learning Inventory) designed by Horwitz (1981).

** Used the same beliefs questionnaire as the present study. 


\subsection{Foreign Language Learning Anxiety}

Researchers view anxiety as a central problem in learning and have proposed various different ways to define it. Scovel (1978) defined anxiety as 'a state of apprehension, a vague fear' (p.134). Spielberger (1983) defined anxiety as 'the subjective feeling of tension, apprehension, nervousness, and worry associated with an arousal of the autonomic nervous system' (p.1). According to Brown (1987), anxiety is 'associated with feelings of uneasiness, self-doubt, apprehension, or worry' (p.106). After reviewing the few scattered studies on this construct, MacIntyre and Gardner (1991) proposed three approaches to investigate anxiety; namely trait, state, and situation-specific. The trait perspective 'considers anxiety as a general personality trait that is relevant across several situations', while the state viewpoint is 'interested in the here-and-now experience of anxiety as an emotional state'. The situation-specific approach 'examines the specific forms of anxiety that occur consistently over time within a given situation' (MacIntyre \& Gardner, 1991: p.87). In short, situation-specific anxiety is the anxiety experienced in a certain type of situation. The situation-specific approach to studying foreign language anxiety has gained acceptance among many anxiety researchers (e.g., MacIntyre \& Gardner, 1991). Horwitz, Horwitz and Cope (1991) were the first among the pioneers who recognised that foreign language anxiety is a form of situation-specific anxiety (i.e., an individual's tendency to be anxious in a particular time and situation).

Horwitz, Horwitz and Cope (1991) conceptualised foreign language anxiety as a 'distinct complex of self-perceptions, beliefs, feelings, and behaviours related to classroom language learning arising from the uniqueness of the language learning process' (p.31). They argued 'communication apprehension, test anxiety and fear of negative evaluation provide useful conceptual building blocks for a description of foreign language anxiety' (Horwitz et al., 1986, p.128). Oh (1990) also agreed that foreign language anxiety is a 'situation-specific anxiety students experience in [the] classroom which is characterized by negative self-centered thoughts, feelings of inadequacy, fear of failure, and emotional reactions in the classroom' (p.56). Horwitz and her colleagues then developed the Foreign Language Classroom Anxiety Scale (FLCAS) to measure foreign language anxiety in terms of the three aspects mentioned above and it has come to be widely used in foreign language learning research. This is a self-report instrument, eliciting responses of anxiety specific to foreign language classroom settings.

Foreign language anxiety can play both debilitating and facilitating roles in language achievement. 'Facilitating anxiety motivates the learner to "fight" the new learning task; it gears the learner emotionally for approval behavior', while "debilitating anxiety motivates the learner to "flee" the new learning task; it stimulates the individual emotionally to adopt avoidance behavior' (Alpert \& Haber, 1960, p.139). However, studies using the FLCAS to investigate different language groups learning different languages showed a constant negative relationship between foreign language anxiety and language achievement (Horwitz et al., 1986; Philips, 1992; Aida, 1994; Young, 1986; Truitt, 1995; Kunt, 1997; Le, 2004), which implies that anxiety most often plays a debilitating role rather than a facilitating role. As MacIntyre and Gardner (1991) pointed out, foreign language anxiety can interfere with learners' efforts to learn a language and it can also 'interfere with the acquisition, retention and production of the new language' (p.86). It is thought to be 'one of the best predictors of success in the second language' (MacIntyre \& Gardner, 1991, p.96), namely lower anxiety can promote more successful learning. Investigating EFL learners' anxiety is quite meaningful for researchers and teachers who have to think about ways to reduce learners' anxiety when faced with some language learning situations (e.g., the foreign language classroom).

\subsection{Learner Beliefs about Language Learning and Foreign Language Learning Anxiety}

Horwitz, Horwitz and Cope (1986) were among the first to suggest that learners' unrealistic beliefs about language learning may cause their anxiety. Young (1991) also proposed that learner beliefs about language learning are a possible source of foreign language anxiety. Bandura (1982) thought beliefs about self-efficacy may be a source of anxiety. He claimed that anxiety together with emotional states may influence beliefs about self-efficacy.

The results of several empirical studies partially support the above opinions. In Horwitz's (1989) study of 34 beginner Spanish students, she found that students who believe they have aptitude in learning foreign languages are less anxious than students who believe they lack such aptitude. Truitt (1995) conducted a study among 204 Korean EFL students enrolled in undergraduate English courses in Seoul, Korea. The instruments used were Korean versions of BALLI (Beliefs About Language Learning Inventory designed by Horwitz in 1981) and FLCAS. The relationship between learner beliefs and anxiety was examined by using correlations and multiple regression analyses. A significant correlation was found between two beliefs factors (i.e., Self-efficacy and Confidence and Ease of Learning English) and foreign language learning anxiety. 'Korean EFL learners who are self-confident about their English ability and believe that they will be learning English well tend to have less anxiety than their peers without such confidence' (Truitt, 1995, p.104). Oh (1996) investigated learner beliefs about language learning and language anxiety among 195 American university first- and second-year students learning Japanese. The instruments used in the study were also BALLI and FLCAS. The correlations and multiple regression analyses showed that two belief factors were significantly correlated with foreign language learning anxiety, however, the size of the variances of these two factors was small in the multiple regression model, indicating a weak relationship between these two constructs. Later Kunt (1997) conducted a study investigating the relationship between these two constructs among 882 Turkish students learning English in the preparatory schools of two universities located in North Cyprus. One group consisted of 554 students from Eastern Mediterranean University (EMU) and a second group consisted of 328 students from Near East University (NEU). BALLI and FLCAS were used in the study. The results of correlations and multiple regression analyses indicated that there was no strong relationship between learning beliefs about language learning and language anxiety but only one 
beliefs factor (i.e., Self-efficacy and Confidence) in one group (i.e., EMU) was found to have a negative relationship with language anxiety.

Although the results in all these empirical studies pointed to either a weak or no relationship between learner beliefs about language learning and foreign language anxiety, it could not be denied that 'the beliefs language students bring to [the] classroom contribute to anxiety reactions' (Horwitz, 1989, p.58).

\section{Research Questions}

Based on what was mentioned above, this study addresses the following three research questions:

1. What beliefs do Chinese university first-year English majors have about language learning?

2. Do Chinese university first-year English majors report experiencing foreign language learning anxiety?

3. Is there any relationship between the Chinese university first-year English majors' beliefs about language learning and their levels of anxiety when they learn English?

\section{Methods}

\subsection{Participants}

The participants in this study were native speakers of Chinese studying English as a foreign language in China. They were 151 first-year undergraduate students majoring in English language and literature at two important universities in China; 12 male and 139 female. Data were collected at the beginning of October 2010, when the first-year students had been at university for just one month or so. There were 100 who attended a university in Beijing and 51 who attended a university in Canton.

\subsection{Instruments}

The present study used two questionnaires to help answer the research questions: the Learner Beliefs Questionnaire (see Appendix A) and the Foreign Language Classroom Anxiety Scale (FLCAS) (see Appendix B).

The beliefs questionnaire was adapted from the three-section questionnaire used in Tanaka's (2004) study mentioned above. The questionnaire used in the present study retains the 27 closed questions used in Tanaka's questionnaire. The participants were asked to indicate how strongly they agree or disagree with each item. The five-point Likert scale technique was used. The validity of the questionnaire was examined and described explicitly in Tanaka's (2004) study. The results of his study showed that the questionnaire was a valid instrument for investigating learner beliefs. The original version of this questionnaire was in English and it was translated into Chinese by using the backwards translation method in order to ensure the consistency of the meaning conveyed with the original one. The Chinese version was administered to the participants in the present study.

The FLCAS questionnaire adopted the items used in Horwitz, Horwitz and Cope's Foreign Language Classroom Anxiety Scale (FLCAS). This scale had been administered previously in a number of separate studies and its validity was ensured. It consists of 33 items investigating students' foreign language classroom anxiety from three aspects: (1) communication apprehension; (2) test anxiety; and (3) fear of negative evaluation. The original versions of these two questionnaires were in English, but in this study they were translated into Chinese and the Chinese versions were administered in order to avoid the Chinese students misunderstanding the content. Both the Chinese and English versions of each are attached.

\subsection{Procedure}

The Canton students were first gathered together to complete the two questionnaires. They did the beliefs questionnaire first, followed by the FLCAS. Ten days later, the students in Beijing were gathered together in a large classroom to complete the two questionnaires. All the participants finished the questionnaires under supervision and the return rate of the questionnaires was $100 \%$.

\subsection{Data Analysis}

The Statistical Program for Social Sciences Version 19 was used to analyse the data. The statistical procedures included the following: reliability analysis, descriptive analysis, factor analysis, correlation analysis and multiple regression analysis. For all analyses, alpha was set at 0.05 .

\section{Results}

\subsection{Reliability}

Reliability is measured in terms of Cronbach's alpha coefficient, which indicates the internal consistency of the data. According to DeVellis (1991), values ranging from 0.65 to 0.70 indicate an acceptable reliability, while Cronbach's alpha value ranging from 0.70 to 0.80 indicates a fairly good reliability and thus a very good consistency. Table 2 shows the reliability values of the two questionnaires. The alphas were 0.75 for the beliefs questionnaire and 0.76 for the anxiety questionnaire, indicating that the reliability of both questionnaires was fairly good in this particular sample.

Table 2. Reliability ( $\mathrm{N}=151)$

\begin{tabular}{lll}
\hline & Items & Reliability \\
\hline Beliefs & 27 & .75 \\
Anxiety & 33 & .76 \\
\hline
\end{tabular}




\subsection{Descriptive Statistics of the Questionnaires}

Table 3-a presents means, ranges and standard deviations of the scores for the two questionnaires. The table shows that the means of the beliefs questionnaire and the FLCAS questionnaire were 97.5 (total possible score 135) and 92.5 (total possible score 165) respectively. The distribution of the scores for each questionnaire was reflected by the standard deviations. Both SDs were small, indicating that there was not much difference among the participants in the beliefs they held or their anxiety levels. Comparatively, there was more variation in the students' anxiety $(\mathrm{SD}=10.85)$ than in their beliefs $(\mathrm{SD}=8.61)$. In order to help compare the anxiety levels among students in the present study with learners in previous studies using the FLCAS, the means of those studies are also demonstrated. Table 3-b shows the figures.

Table 3-a. Descriptive Statistics for the Two Questionnaires $(\mathrm{N}=151)$

\begin{tabular}{lcccr}
\hline & Mean & Max. & Min. & SD \\
\hline Beliefs & 97.5 & 126 & 74 & 8.61 \\
Anxiety & 92.5 & 126 & 65 & 10.85 \\
\hline
\end{tabular}

Table 3-b. Means in Studies Using the FLCAS

\begin{tabular}{llc}
\hline & \multicolumn{1}{c}{ Mean } & Participants \\
\hline Present study & 92.5 & 151 Chinese university first-year English majors \\
Horwitz (1986) & 94.5 & 108 American students of Spanish \\
Aida (1994) & 96.7 & 96 American students of Japanese \\
Truitt(1995) & 101.2 & 204 Korean EFL students \\
Kunt (1997) EMU & 89.4 & 554 Turkish EFL students \\
Kunt (1997) NEU & 90.8 & 328 Turkish EFL students \\
\hline
\end{tabular}

Note. There were two groups in Kunt's (1997) study. EMU refers to the students from the Easten Mediterranean University and NEU refers to the students from the Near East University.

\subsection{Factor Analysis of Learner Beliefs Questionnaire}

A principal factor analysis and then a subsequent factor analysis were conducted on the responses to the beliefs questionnaire in order to reduce the variables into several manageable factors and to address the first research question concerning the learner beliefs held by Chinese university first-year English majors.

Factor analysis 'is a statistical method used to find a small set of unobserved variables (also called latent variables, or factors) which can account for the covariance among a larger set of observed variables (also called manifest variables)'(Albright \& Park, 2009, p.2). Principal Factor analysis was first done with a Varimax rotation. Nine factors were obtained with eigenvalues equal to or greater than 1. Nine factors are far too many, hence a 'scree plot' was used to select the factors that significantly represent the total variance. When the scree-plot test was applied, four factors seemed to meet the criteria and thus four of them were selected. See Appendix C for details.

The method of Principal Axis Factoring was then conducted with the four selected factors. Table 4 demonstrates the results, indicating that the items loaded on four different factors. This solution accounted for $40 \%$ of the total questionnaire variance. The items which had a loading of 0.40 or higher were used for interpretation of the factors. It could be seen that seven items loaded on Factor 1 (e.g., 'I can learn well by speaking to others in English') with loadings that ranged from 0.40 to 0.68 . The items with high loadings on Factor 1 seemed to have in common the idea that the approach to learning English is very important, including using English outside class, reviewing what they have been taught in class etc. Thus, Factor 1 was labelled 'approach to learning', which had been found among Hong Kong students in Benson and Lor's (1999) study mentioned in Table 1. The Cronbach's alpha for Factor 1 was 0.73 . Six items loaded on Factor 2 (e.g., 'It is possible for me to learn to speak English very well') with loadings from 0.40 to 0.78. These items indicated the respondents' belief that they had the potential to speak English well and understand everything in English. Therefore, this factor was labelled 'self-efficacy and confidence in English', beliefs found among the EFL students in several studies mentioned in Table 1 (e.g., Truitt, 1995; Kunt, 1997). The reliability alpha for Factor 2 was 0.75 . Factor 3 had five items loaded on it (e.g., 'I can learn English well by following a textbook') with loadings from 0.41 to 0.61 . These items revealed that students held common beliefs about formal and structured learning. Hence, this factor was labelled 'formal and structured learning', which had been found among the EFL students in several studies mentioned in Table 1 (e.g., Yang, 1992; Truitt, 1995). The reliability value of this factor was 0.56. Just two items loaded on Factor 4 ('It doesn't matter if I make mistakes when speaking with others in English') with loadings from 0.43 to 0.47 . Students seemed to believe that they can learn English well if they learn it without any pressure. Thus, this factor was labelled 'ease of learning English', which had been found among EFL students in several studies mentioned in Table 1 (e.g., Truitt, 1995; Kunt, 1997). The reliability value of this factor is 0.32 . All reliability alphas of these factors were acceptable except that of Factor 4, where the relatively low number of items (two items) may explain the low reliability (Yang, 1992). 
Table 4. Promax Rotated Matrix with Requesting Four Factors

\begin{tabular}{|c|c|c|c|c|c|}
\hline Component & Eigenvalues & \multicolumn{2}{|c|}{$\%$ of Variance } & \multicolumn{2}{|c|}{ Cumulative \% } \\
\hline 1 & 4.903 & \multicolumn{2}{|c|}{18.159} & \multicolumn{2}{|c|}{18.159} \\
\hline 2 & 2.538 & \multicolumn{2}{|c|}{9.401} & \multicolumn{2}{|c|}{27.569} \\
\hline 3 & 1.949 & \multicolumn{2}{|c|}{7.217} & \multicolumn{2}{|c|}{34.777} \\
\hline 4 & 1.604 & \multicolumn{2}{|c|}{5.941} & \multicolumn{2}{|c|}{40.718} \\
\hline & & 1 & 2 & 3 & 4 \\
\hline \multicolumn{2}{|c|}{ Item 1} & 0.679 & -0.109 & -0.200 & 0.307 \\
\hline \multicolumn{2}{|c|}{ Item 2} & -0.126 & 0.112 & 0.149 & -0.092 \\
\hline \multicolumn{2}{|c|}{ Item 3} & 0.384 & 0.126 & 0.051 & 0.192 \\
\hline \multicolumn{2}{|c|}{ Item 4} & 0.127 & -0.108 & 0.410 & 0.091 \\
\hline \multicolumn{2}{|c|}{ Item 5} & 0.143 & -0.125 & 0.140 & -0.400 \\
\hline \multicolumn{2}{|c|}{ Item 6} & 0.183 & -0.156 & 0.023 & 0.465 \\
\hline \multicolumn{2}{|c|}{ Item 7} & 0.433 & -0.124 & 0.267 & -0.306 \\
\hline \multicolumn{2}{|c|}{ Item 8} & 0.046 & 0.462 & 0.282 & 0.111 \\
\hline \multicolumn{2}{|c|}{ Item 9} & 0.392 & 0.060 & 0.026 & -0.231 \\
\hline \multicolumn{2}{|c|}{ Item 10} & 0.576 & 0.002 & 0.110 & 0.138 \\
\hline \multicolumn{2}{|c|}{ Item 11} & 0.404 & -0.076 & 0.226 & -0.155 \\
\hline \multicolumn{2}{|c|}{ Item 12} & 0.388 & -0.037 & 0.036 & 0.171 \\
\hline \multicolumn{2}{|c|}{ Item 14} & -0.195 & 0.045 & 0.453 & 0.252 \\
\hline \multicolumn{2}{|c|}{ Item 15} & 0.075 & 0.066 & 0.238 & 0.432 \\
\hline \multicolumn{2}{|c|}{ Item 16} & 0.120 & 0.205 & 0.151 & 0.327 \\
\hline \multicolumn{2}{|c|}{ Item 17} & -0.222 & -0.121 & 0.456 & 0.017 \\
\hline \multicolumn{2}{|c|}{ Item 18} & -0.008 & 0.096 & 0.503 & -0.093 \\
\hline \multicolumn{2}{|c|}{ Item 19} & 0.569 & 0.053 & -0.038 & 0.033 \\
\hline \multicolumn{2}{|c|}{ Item 20} & -0.051 & 0.629 & 0.091 & 0.063 \\
\hline \multicolumn{2}{|c|}{ Item 21} & 0.227 & 0.469 & -0.096 & 0.131 \\
\hline & & 0.571 & 0.102 & -0.050 & -0.111 \\
\hline & & -0.062 & 0.778 & -0.042 & -0.088 \\
\hline & & 0.608 & 0.203 & -0.212 & -0.045 \\
\hline & & 0.135 & 0.401 & 0.050 & -0.172 \\
\hline $\begin{array}{r}\text { It } \\
\text { Table } 4\end{array}$ & $\begin{array}{l}26 \\
\text { ontinued) }\end{array}$ & 0.045 & 0.567 & -0.159 & -0.090 \\
\hline & & 0.020 & 0.146 & 0.223 & -0.295 \\
\hline
\end{tabular}

Extraction Method: Principal Axis Factoring

Rotation Method: Promax with Kaiser Normalization

a. Rotation converged in 14 iterations.

\subsection{Descriptive Statistics for Items in Beliefs Questionnaire}

Table 5 (a-d) shows the descriptive statistics of each item in the beliefs questionnaire including frequency analysis, mean (M) and standard deviation (SD). The highest value for each item is 5 . The higher the value, the more strongly the student holds the belief. As a whole, students scored Factor 1 the highest $(\mathrm{M}=4.00)$, followed by Factor $2(\mathrm{M}=3.94)$ and then Factor $4(\mathrm{M}=3.09)$. They seemed to place the lowest importance on Factor $3(\mathrm{M}=2.94)$. In terms of Factor 1, students scored Item 24 the highest $(\mathrm{M}=4.21)$, followed by Item $19(\mathrm{M}=4.08)$. They did not demonstrate much difference on Item $7(\mathrm{M}=4.03)$ and Item $1(\mathrm{M}=4.02)$. They scored Item 22 the lowest $(\mathrm{M}=3.88)$. All SDs were rather small, indicating that there was not much difference in the students' opinions. Turning to Factor 2, students seemed to hold very strong beliefs on item $25(\mathrm{M}=4.38)$ regarding the importance of learning vocabulary for them to speak English well. They also strongly believed that they could learn to speak English well (Item 23, M=4.26). Students scored Factor 3 the lowest $(M=2.94)$ compared with the other factors. Within Factor 3, they scored item 17 the highest $(\mathrm{M}=3.46)$, indicating that they held the strong belief that they could understand everything if their teachers explained important points in their native language. In Tanaka's (2004) study, the participants' scores for all items were much lower than in the present study except on items 19, 22, 25, 4, 17, 6 and 15. Participants in Tanaka's study seemed to hold stronger beliefs in their ability to use English, and in that English learning could be done for pleasure than the participants in the present study. 
Table 5-a. Factor 1 (Total Mean: M=4.00)

\begin{tabular}{|c|c|c|c|c|c|c|c|}
\hline Items & 5 & 4 & 3 & 2 & 1 & Mean & SD \\
\hline \multirow{2}{*}{$\begin{array}{l}\text { I can learn well by speaking with } \\
\text { others in English. (Item1) }\end{array}$} & \multirow{2}{*}{$\begin{array}{l}31.8 \% \\
(48)\end{array}$} & \multirow{2}{*}{$\begin{array}{l}43.7 \% \\
(66)\end{array}$} & \multirow{2}{*}{$\begin{array}{l}19.2 \% \\
(29)\end{array}$} & \multirow{2}{*}{$\begin{array}{l}5.3 \% \\
(8)\end{array}$} & \multirow{2}{*}{$\begin{array}{l}0 \% \\
(0)\end{array}$} & $4.02(\mathrm{M})$ & $.85(\mathrm{M})$ \\
\hline & & & & & & $4.13(\mathrm{~T})$ & $.66(\mathrm{~T})$ \\
\hline \multirow{2}{*}{$\begin{array}{l}\text { Important to review what's been } \\
\text { taught in class. (Item 7) }\end{array}$} & \multirow{2}{*}{$\begin{array}{l}32.5 \% \\
(49)\end{array}$} & \multirow{2}{*}{$\begin{array}{l}48.3 \% \\
(73) \\
\end{array}$} & \multirow{2}{*}{$\begin{array}{l}10.6 \% \\
(16)\end{array}$} & \multirow{2}{*}{$\begin{array}{l}6.6 \% \\
(10)\end{array}$} & \multirow{2}{*}{$\begin{array}{l}2 \% \\
(3)\end{array}$} & $4.03(\mathrm{M})$ & $.94(\mathrm{M})$ \\
\hline & & & & & & $4.14(\mathrm{~T})$ & $.71(\mathrm{~T})$ \\
\hline \multirow{2}{*}{$\begin{array}{l}\text { I can learn English well by } \\
\text { listening to radio or watching TV } \\
\text { in English. (Item 10) }\end{array}$} & \multirow{2}{*}{$\begin{array}{l}16.6 \% \\
(25)\end{array}$} & \multirow{2}{*}{$\begin{array}{l}56.3 \% \\
(85)\end{array}$} & \multirow{2}{*}{$\begin{array}{l}19.2 \% \\
(29)\end{array}$} & \multirow{2}{*}{$\begin{array}{l}7.9 \% \\
(12)\end{array}$} & \multirow{2}{*}{$\begin{array}{l}0 \% \\
(0)\end{array}$} & $3.81(\mathrm{M})$ & $.80(\mathrm{M})$ \\
\hline & & & & & & $4.33(\mathrm{~T})$ & $.68(\mathrm{~T})$ \\
\hline \multirow{2}{*}{$\begin{array}{l}\text { Memorisation is a good way. } \\
\text { (Item 11) }\end{array}$} & \multirow{2}{*}{$\begin{array}{l}25.2 \% \\
(38)\end{array}$} & \multirow{2}{*}{$\begin{array}{l}57 \% \\
(86)\end{array}$} & \multirow{2}{*}{$\begin{array}{l}10.6 \% \\
(16)\end{array}$} & \multirow{2}{*}{$\begin{array}{l}6.6 \% \\
(10)\end{array}$} & \multirow{2}{*}{$\begin{array}{l}0.7 \% \\
(1)\end{array}$} & $3.99(\mathrm{M})$ & $.83(\mathrm{M})$ \\
\hline & & & & & & $3.71(\mathrm{~T})$ & $.89(\mathrm{~T})$ \\
\hline \multirow{2}{*}{$\begin{array}{l}\text { I can learn well by using English } \\
\text { outside class. (Item 19) }\end{array}$} & \multirow{2}{*}{$\begin{array}{l}19.2 \\
(29)\end{array}$} & \multirow{2}{*}{$\begin{array}{l}69.5 \\
(105)\end{array}$} & \multirow{2}{*}{$\begin{array}{l}11.3 \\
(29)\end{array}$} & \multirow{2}{*}{$\begin{array}{l}0 \% \\
(0)\end{array}$} & \multirow{2}{*}{$\begin{array}{l}0 \% \\
(0)\end{array}$} & $4.08(\mathrm{M})$ & $.55(\mathrm{M})$ \\
\hline & & & & & & $4.16(\mathrm{~T})$ & $.70(\mathrm{~T})$ \\
\hline \multirow{2}{*}{$\begin{array}{lr}\text { I can learn well by reading } \\
\text { English magazines } & \text { or } \\
\text { newspapers.(Item 22) } & \end{array}$} & \multirow{2}{*}{$\begin{array}{l}17.2 \% \\
(26)\end{array}$} & \multirow{2}{*}{$\begin{array}{l}58.3 \% \\
(88)\end{array}$} & \multirow{2}{*}{$\begin{array}{l}19.9 \% \\
(30)\end{array}$} & \multirow{2}{*}{$\begin{array}{l}4.6 \% \\
(7)\end{array}$} & \multirow{2}{*}{$\begin{array}{l}0 \% \\
(0)\end{array}$} & $3.88(\mathrm{M})$ & $.74(\mathrm{M})$ \\
\hline & & & & & & $3.91(\mathrm{~T})$ & $.61(\mathrm{~T})$ \\
\hline \multirow{2}{*}{$\begin{array}{l}\text { I can learn well if I try to think in } \\
\text { English. (Item 24) }\end{array}$} & \multirow{2}{*}{$\begin{array}{l}33.8 \% \\
(51)\end{array}$} & $54.3 \%$ & $11.3 \%$ & $0.7 \%$ & $0 \%$ & $4.21(\mathrm{M})$ & $.66(\mathrm{M})$ \\
\hline & & $(82)$ & (17) & (1) & (0) & $3.68(\mathrm{~T})$ & $.92(\mathrm{~T})$ \\
\hline
\end{tabular}

Table 5-b. Factor 2 (Total Mean: M=3.94)

\begin{tabular}{|c|c|c|c|c|c|c|c|}
\hline Items & 5 & 4 & 3 & 2 & 1 & Mean & SD \\
\hline \multirow{2}{*}{$\begin{array}{l}\text { Able to understand everything } \\
\text { read in English. (Item } 8 \text { ) }\end{array}$} & \multirow{2}{*}{$\begin{array}{l}13.9 \% \\
(21)\end{array}$} & \multirow{2}{*}{$\begin{array}{l}35.8 \% \\
(54)\end{array}$} & \multirow{2}{*}{$\begin{array}{l}36.4 \% \\
(55)\end{array}$} & \multirow{2}{*}{$\begin{array}{l}12.6 \% \\
(19)\end{array}$} & \multirow{2}{*}{$\begin{array}{l}1.3 \% \\
(2)\end{array}$} & $3.48(\mathrm{M})$ & $0.93(\mathrm{M})$ \\
\hline & & & & & & $2.81(\mathrm{~T})$ & $0.69(\mathrm{~T})$ \\
\hline \multirow{2}{*}{$\begin{array}{l}\text { Able to understand everything } \\
\text { the teacher says. (Item 20) }\end{array}$} & \multirow{2}{*}{$\begin{array}{l}10.6 \\
(16)\end{array}$} & \multirow{2}{*}{$\begin{array}{l}37.7 \% \\
(57)\end{array}$} & \multirow{2}{*}{$\begin{array}{l}41.1 \% \\
(62)\end{array}$} & \multirow{2}{*}{$\begin{array}{l}9.3 \% \\
(14)\end{array}$} & \multirow{2}{*}{$\begin{array}{l}1.3 \% \\
(2)\end{array}$} & $3.47(\mathrm{M})$ & $0.86(\mathrm{M})$ \\
\hline & & & & & & $3.25(\mathrm{~T})$ & $0.76(\mathrm{~T})$ \\
\hline \multirow{2}{*}{$\begin{array}{l}\text { It's okay to guess if I don't } \\
\text { know a word. (Item 21) }\end{array}$} & \multirow{2}{*}{$\begin{array}{l}31.1 \% \\
(47)\end{array}$} & \multirow{2}{*}{$\begin{array}{l}52.3 \% \\
(79)\end{array}$} & \multirow{2}{*}{$\begin{array}{l}11.9 \% \\
(18)\end{array}$} & \multirow{2}{*}{$\begin{array}{l}4 \% \\
(6)\end{array}$} & \multirow{2}{*}{$\begin{array}{l}0.7 \% \\
(1)\end{array}$} & $4.09(\mathrm{M})$ & $0.80(\mathrm{M})$ \\
\hline & & & & & & $3.58(\mathrm{~T})$ & $0.74(\mathrm{~T})$ \\
\hline \multirow{2}{*}{$\begin{array}{l}\text { It's possible for me to speak } \\
\text { English very well. (Item 23) }\end{array}$} & \multirow{2}{*}{$\begin{array}{l}43 \% \\
(65)\end{array}$} & \multirow{2}{*}{$\begin{array}{l}45 \% \\
(68)\end{array}$} & \multirow{2}{*}{$\begin{array}{l}8.6 \% \\
(13)\end{array}$} & \multirow{2}{*}{$\begin{array}{l}1.3 \% \\
(2)\end{array}$} & \multirow{2}{*}{$\begin{array}{l}2 \% \\
(3)\end{array}$} & $4.26(\mathrm{M})$ & $0.83(\mathrm{M})$ \\
\hline & & & & & & & (T) \\
\hline \multirow{2}{*}{$\begin{array}{l}\text { In order to speak English well, } \\
\text { it is important to learn } \\
\text { vocabulary. (Item 25) }\end{array}$} & \multirow{2}{*}{$\begin{array}{l}41.1 \% \\
(62)\end{array}$} & \multirow{2}{*}{$\begin{array}{l}56.3 \% \\
(85)\end{array}$} & \multirow{2}{*}{$\begin{array}{l}2.6 \% \\
(4)\end{array}$} & \multirow{2}{*}{$\begin{array}{l}0 \% \\
(0)\end{array}$} & \multirow{2}{*}{$\begin{array}{l}0 \% \\
(0)\end{array}$} & 4.3 & $0.54(\mathrm{M})$ \\
\hline & & & & & & $4.42(\mathrm{~T})$ & $0.72(\mathrm{~T})$ \\
\hline \multirow{2}{*}{$\begin{array}{l}\text { It's possible for me not to get } \\
\text { nervous when speaking } \\
\text { English. (Item 26) }\end{array}$} & \multirow{2}{*}{$\begin{array}{l}27.8 \\
(42)\end{array}$} & \multirow{2}{*}{$\begin{array}{l}47.7 \\
(72)\end{array}$} & \multirow{2}{*}{$\begin{array}{l}20.5 \\
(31)\end{array}$} & \multirow{2}{*}{$\begin{array}{l}2.6 \\
(4)\end{array}$} & \multirow{2}{*}{$\begin{array}{l}1.3 \\
(2)\end{array}$} & $3.98(\mathrm{M})$ & $0.84(\mathrm{M})$ \\
\hline & & & & & & $2.48(\mathrm{~T})$ & 1.04(T) \\
\hline
\end{tabular}

Table 5-c. Factor 3 (Total Mean: M=2.94)

\begin{tabular}{|c|c|c|c|c|c|c|c|}
\hline Items & 5 & 4 & 3 & 2 & 1 & Mean & SD \\
\hline \multirow{2}{*}{$\begin{array}{l}\text { I can learn English well by } \\
\text { writing down everything in my } \\
\text { notebook. (Item 4) }\end{array}$} & \multirow{2}{*}{$\begin{array}{l}0.7 \% \\
(22)\end{array}$} & \multirow{2}{*}{$\begin{array}{l}12.6 \% \\
(59)\end{array}$} & \multirow{2}{*}{$\begin{array}{l}31.1 \% \\
(60)\end{array}$} & \multirow{2}{*}{$\begin{array}{l}43 \% \\
(9)\end{array}$} & \multirow{2}{*}{$\begin{array}{l}12.6 \% \\
(1)\end{array}$} & $2.46(\mathrm{M})$ & $0.89(\mathrm{M})$ \\
\hline & & & & & & $2.65(\mathrm{~T})$ & $0.80(\mathrm{~T})$ \\
\hline \multirow{2}{*}{$\begin{array}{l}\text { Learn English well by following } \\
\text { a text book. (Item 13) }\end{array}$} & \multirow{2}{*}{$\begin{array}{l}2 \% \\
(3)\end{array}$} & \multirow{2}{*}{$\begin{array}{l}16.6 \% \\
(25)\end{array}$} & \multirow{2}{*}{$\begin{array}{l}44.4 \% \\
(67)\end{array}$} & \multirow{2}{*}{$\begin{array}{l}32.5 \% \\
(49)\end{array}$} & \multirow{2}{*}{$\begin{array}{l}4.6 \% \\
(7)\end{array}$} & 2.79(M) & $0.85(\mathrm{M})$ \\
\hline & & & & & & 2.74 & 0.9 \\
\hline \multirow{2}{*}{$\begin{array}{l}\text { I should not be forced to speak in } \\
\text { English class. (Item 14) }\end{array}$} & \multirow{2}{*}{$\begin{array}{l}5.3 \% \\
(8)\end{array}$} & \multirow{2}{*}{$\begin{array}{l}17.2 \% \\
(26)\end{array}$} & \multirow{2}{*}{$\begin{array}{l}24.5 \% \\
(37) \\
\end{array}$} & \multirow{2}{*}{$\begin{array}{l}39.7 \% \\
(60)\end{array}$} & \multirow{2}{*}{$\begin{array}{l}13.2 \% \\
(20)\end{array}$} & 2.62 & $1.08(\mathrm{M})$ \\
\hline & & & & & & & \\
\hline \multirow{2}{*}{$\begin{array}{l}\text { Explain important things in my } \\
\text { first language so I can understand } \\
\text { everything. (Item 17) }\end{array}$} & \multirow{2}{*}{$\begin{array}{l}15.9 \% \\
(24)\end{array}$} & \multirow{2}{*}{$\begin{array}{l}41.1 \% \\
(62)\end{array}$} & \multirow{2}{*}{$\begin{array}{l}20.5 \% \\
(31)\end{array}$} & \multirow{2}{*}{$\begin{array}{l}18.5 \% \\
(28)\end{array}$} & \multirow{2}{*}{$\begin{array}{l}4 \% \\
(6)\end{array}$} & $3.46(\mathrm{M})$ & $1.09(\mathrm{M})$ \\
\hline & & & & & & 3.5 & $0.87(\mathrm{~T})$ \\
\hline \multirow{2}{*}{$\begin{array}{l}\text { I can learn English well in a class } \\
\text { where the teacher maintains good } \\
\text { discipline. (Item 18) }\end{array}$} & \multirow{2}{*}{$\begin{array}{l}8.6 \% \\
(13)\end{array}$} & \multirow{2}{*}{$\begin{array}{l}39.7 \% \\
(60)\end{array}$} & \multirow{2}{*}{$\begin{array}{l}35.1 \% \\
(53)\end{array}$} & \multirow{2}{*}{$\begin{array}{l}13.9 \% \\
(21)\end{array}$} & \multirow{2}{*}{$\begin{array}{l}2.6 \% \\
(4)\end{array}$} & 3.38 & $0.922(\mathrm{M})$ \\
\hline & & & & & & 3.2 & 0 . \\
\hline
\end{tabular}

Table 5-d. Factor 4 (Total Mean: M=3.09)

\begin{tabular}{|l|l|l|l|l|l|l|l|}
\hline Items & 5 & 4 & 3 & 2 & 1 & Mean & SD \\
\hline $\begin{array}{l}\text { It doesn't matter if I make } \\
\text { mistakes when speaking with } \\
\text { others in English. (Item 6) }\end{array}$ & $\begin{array}{l}8.6 \% \\
(13)\end{array}$ & $\begin{array}{l}29.1 \% \\
(44)\end{array}$ & $\begin{array}{l}20.5 \% \\
(31)\end{array}$ & $\begin{array}{l}33.8 \% \\
(51)\end{array}$ & $\begin{array}{l}7.9 \% \\
(12)\end{array}$ & $2.97(\mathrm{M})$ & $1.14(\mathrm{M})$ \\
\hline $\begin{array}{l}\text { I can learn English well if I'm } \\
\text { studying just for pleasure. }\end{array}$ & $\begin{array}{l}13.9 \% \\
(21)\end{array}$ & $\begin{array}{l}21.9 \% \\
(33)\end{array}$ & $\begin{array}{l}36.4 \% \\
(55)\end{array}$ & $\begin{array}{l}25.2 \% \\
(38)\end{array}$ & $\begin{array}{l}2 \% \\
(3)\end{array}$ & $3.21(\mathrm{M})$ & $1.17(\mathrm{~T})$ \\
\cline { 5 - 8 } & & & & & $1.25(\mathrm{~T})$ & $0.91(\mathrm{M})$ \\
\hline
\end{tabular}


Note:

(1) $5=$ Strongly Agree, $4=$ Agree, $3=$ Neutral, $2=$ Disagree, $1=$ Strongly Disagree

(2) $\mathrm{M}$ and T: M refers to the means and standard deviations in the present study, while T refers to the means and standard deviations in Tanaka's (2004) study.

\subsection{Correlations and Multiple Regression Analyses for Learner Beliefs and Anxiety}

In order to address the third research question, Pearson's correlation analysis was conducted to examine the relationships between learner beliefs and anxiety. Table 6 presents the results. Pearson's correlation coefficient (r) 'is the standard measure of the linear relationship between two variables' (Cohen, et al.,2003,p.28). According to Cohen (1988 and 2003), a correlation coefficient ranging from .10 to .29 is thought to represent a weak or small correlation; a correlation coefficient ranging from .30 to .49 is considered a moderate correlation; and a correlation coefficient of .50 or larger is thought to represent a strong or large correlation. Therefore, no significant relationship was found between learner beliefs and anxiety, but two relationships were found between two particular factors of learner beliefs and anxiety. Factor 2, concerning beliefs about self-efficacy and confidence, was found to have a significant negative relationship with anxiety, however, the coefficient was low $(\mathrm{r}=-0.183)$ indicating the relationship was weak. It was surprising to find a significant positive relationship between Factor 3, regarding beliefs about formal and structured learning, and anxiety but the relationship was also weak. In order to investigate which factor could best predict language anxiety, a Stepwise multiple regression analysis was administered. Table7 demonstrates the results. From this table, it could be seen that Factor 3 together with Factor 2 could predict anxiety $(\mathrm{F}=9.923, \mathrm{P}<.05)$. The value for the multiple R when predicting foreign language anxiety from beliefs factors 3 and 2 was .344. R Square (R2) indicates the proportion of the variance in the dependent variable which is accounted for by the model. However, it 'tends to somewhat over-estimate the success of the model when applied to the real world, so an Adjusted R Square value is calculated which takes into account the number of variables in the model and the number of observations (participants) our model is based on' (Brace, Kemp\& Snelgar, 2006,p.209). Accordingly, it can be seen from Table 7 that Factor 3 and Factor 2 of learner beliefs could only account for $10.6 \%$ of the variance in the foreign language anxiety scores in this sample indicating the size of the variances of these two factors was small in the multiple regression model.

This table also shows the respective beta values of Factor 3 and Factor 2. 'Beta value is a measure of how strongly each predictor variable influences the dependent variable' and 'the higher the beta value the greater the impact of the predictor variable on the dependent variable' (Brace, Kemp\& Snelgar, 2006,p. 208). Hence, in the case of this sample, Factor 3 seemed to be a better predictor of foreign language anxiety (Beta $=0.297, \mathrm{p}<.05)$.

Table 6. Correlations between Learner Beliefs and Anxiety.

\begin{tabular}{ll}
\hline & Anxiety \\
\hline Learner beliefs & 0.021 \\
Factor 1 & -0.089 \\
Factor 2 & $-0.172 *$ \\
Factor 3 & $0.298 * *$ \\
Factor 4 & 0.088 \\
\hline$* \mathrm{p}<0.01 \quad * \mathrm{p}<0.05$ &
\end{tabular}

Table 7. Stepwise multiple regression analysis for foreign language anxiety

\begin{tabular}{|c|c|c|c|}
\hline Model & Beta & $\mathrm{t}$ & Sig. (p) \\
\hline Factor 3 & .297 & 3.854 & .000 \\
\hline Factor 2 & -.172 & -2.224 & .028 \\
\hline $\mathrm{R}=.344$ & $\mathrm{R}^{2}=.118$ & Adjusted $\mathrm{R}^{2}=.106$ & $F=9.923$ Sig. $=.000$ \\
\hline
\end{tabular}

\subsection{Correlations and Multiple Regression Analysis of Learner Beliefs Items and Anxiety}

Pearson's correlation analysis was carried out again to investigate the relationships between each item in the two questionnaires. Table 8 presents the results. Seven relationships were found between scores on learner beliefs items and scores on anxiety. It was quite interesting to find that not all the relationships were negative. Among all the correlations four were negative (i.e., item 1, item 16, item 20 and item 26 had negative relationships with anxiety) and four were positive (i.e., item 4, item 14, item 17 had positive relationships with anxiety). However, in all cases the coefficients 
were low (less than 0.29), indicating all the relationships were weak. In order to explore which item(s) could predict language anxiety, I then conducted a multiple regression analysis of learner beliefs items to anxiety using a Stepwise method. Table 9 demonstrates the results. The model with five items (items 26, 16, 14, 12 and 1) seemed to predict language anxiety. However, the Adjusted R square of this model was low, it could only account for $20.7 \%$ of the variance of language anxiety, pointing to weak relationships between learner beliefs items and language anxiety. Item 26 (i.e., 'It is possible for me not to get nervous when speaking English') seemed to be the best predictor of language anxiety $($ Beta $=-0.234, \mathrm{p}<.05)$.

Table 8. Correlations between Learner Beliefs Items and Anxiety

\begin{tabular}{|c|c|}
\hline & Anxiety \\
\hline Item 1 & $-0.219 * *$ \\
\hline Item 2 & 0.139 \\
\hline Item3 & -0.064 \\
\hline Item 4 & $0.169 *$ \\
\hline Item 5 & -0.044 \\
\hline Item 6 & 0.048 \\
\hline Item 7 & 0.088 \\
\hline Item 8 & -0.041 \\
\hline Item 9 & -0.008 \\
\hline Item 10 & -0.150 \\
\hline Item 11 & 0.109 \\
\hline Item 12 & 0.131 \\
\hline Item 13 & 0.110 \\
\hline Item 14 & $0.222 * *$ \\
\hline Item 15 & 0.090 \\
\hline Item 16 & $-0.269 * *$ \\
\hline Item 17 & $0.238 * *$ \\
\hline Item 18 & 0.140 \\
\hline Item 19 & -0.074 \\
\hline Item 20 & $-0.179 *$ \\
\hline Item 21 & -0.105 \\
\hline Item 22 & -0.089 \\
\hline Item 23 & -0.089 \\
\hline Item 24 & -0.083 \\
\hline Item 25 & 0.041 \\
\hline Item 26 & $-0.269 * *$ \\
\hline Item 27 & 0.117 \\
\hline
\end{tabular}

Table 9. Stepwise multiple regression analysis for foreign language anxiety

\begin{tabular}{llll}
\hline Model & Beta & \multicolumn{1}{c}{$\mathrm{t}$} & Sig. $(\mathrm{p})$ \\
\hline Item 26 & -.234 & -3.137 & .002 \\
Item 16 & -.232 & -3.106 & .002 \\
Item 14 & .201 & 2.725 & .007 \\
Item 12 & .193 & 2.529 & .013 \\
Item 1 &.-.173 & -2.209 & .029 \\
\hline $\mathrm{R}=.484$ & $\mathrm{R}^{2}=.234$ & Adjusted $\mathrm{R}^{2}=.207$ & $\mathrm{~F}=8.794$ \\
& & & Sig. $=.000$
\end{tabular}

Note. Method: Stepwise (Criteria: Probability-of-F-to-enter $<=.050$, Probability-of- F-to-remove $>=.100$ ) Predictors: Item 26, Item 16, Item 14, Item 12, Item 1 (Learner Beliefs)

Dependent Variable: foreign language anxiety

\section{Discussions and Conclusions}

To investigate the first research question, regarding what beliefs Chinese first-year English majors have about language learning, I used the beliefs questionnaire designed by Tanaka (2004). As reviewed above, there are four ways to categorise learner beliefs, namely logically-derived, empirically-derived, inductively-derived and deductively-derived. Tanaka (2004) adopted the fourth way and identified three types of learner beliefs among Japanese EFL learners at home and abroad. The present study adopted the empirically-derived method and I used Principal Component analysis as well as subsequent factor analysis to explore what beliefs Chinese first-year English majors held about language learning. Four types of learner beliefs were revealed among the students; 'approach to learning English', 'self-efficacy and confidence in English', 'formal and structured learning' and 'ease of learning English'. The results reveal that the students generally share a belief that approaches to learning English are very important for them to learn English well. They also believe that they will be able to learn to speak English very well. Chinese learners have been described as quiet and reluctant to ask questions or express their own opinions publicly (Ballard \& Clanchy, 1991). However, the emergence of the category of learner beliefs in self-efficacy and confidence may indicate that Chinese EFL learners are beginning to change their ways and they may be more active in expressing themselves nowadays. Compared with 
formal and structured learning, Chinese university first-year English majors held stronger beliefs on the importance of learning English for pleasure.

Looking at the items in each factor closely, there seemed to be odd items in Factor 2. Odd items here refer to those items which seemed to express different ideas from other items. In Factor 2, items 21 ('It's okay to guess if I don't know a word') and 25 ('In order to speak English well, it is important to learn vocabulary') seemed to be about learning strategies more than self-efficacy and confidence. However, if we think about them carefully, it is not difficult to find that 'it's okay to guess' also reveals something of the learners' confidence, because 'guessing strategy' is often studied in research on L1 reading and 'it is the only reasonable way for L2 learners to learn enough words to form suitably large active and passive vocabularies' (Dycus, 1997, p.2). In other words, if students think it is okay to guess, it means they are confident in their vocabulary and they believe that they can guess. In terms of their common beliefs in the importance of English vocabulary, we may treat it as a source of their self-efficacy and confidence in speaking English.

Examining the items in Factor 1, different ways of learning English were revealed, including learning English through using English outside the classroom, reading English, watching or listening to English programmes and memorising. These first-year English majors seemed to allocate the lowest scores to memorising and gave relatively higher scores on items relative to using English outside the classroom, which indicated that the Chinese students believed that using English was more effective than memorising for them to learn English well. Two reasons may explain why students have stronger beliefs on items relative to learning English well through using English more than through structured learning. The first may be attributed to the teaching methods adopted at universities nowadays. Universities in China began to adopt communicative methods 20 years ago, especially for English majors. The requirements for English majors are much higher than for students studying English not as their major subject because 'proper and efficient' communication rather than 'can-do communication' is emphasised. The second reason for their stronger beliefs in learning English through using it may be that the English environment is better than before. Nowadays, students have more English resources to enable them to learn English well, including English-language TV programmes, movies, magazines and online resources. Students can even access programmes made in English-speaking countries. In the meantime, due to the fact that China has opened to the outside world and the economy is developing very fast, more and more people from English-speaking countries come to China, to learn Chinese, to teach English and to do business. Therefore, students have more chances to use English inside and outside the classroom and they are more willing to communicate with the outside in order to learn English well rather than following textbooks or learning grammar alone.

Comparing the students' scores on the items in the beliefs questionnaire in the present study with those in Tanaka's (2004) study, the students seemed to share some common beliefs no matter whether they were Japanese or Chinese. For example, the two groups both gave high scores to item 25: 'In order to speak English well, it is important for me to learn vocabulary'. In both studies, students scored relatively low for the items in Factor 3 labelled 'formal and structured learning' in the present study

Turning to the second research question, in terms of whether Chinese university first-year English majors reported experiencing anxiety about foreign language learning, the answer should be yes. The students in this study reported that they experienced anxiety, but with a mean relatively lower than that of subjects in several previous studies (refer to Table 3-b). Specifically, the FLCAS mean score of the students in this study was 92.5, which was lower than those of Horwitz's (1986) study of American students of Spanish (M=94.5), Aida's (1994) study of American students of Japanese ( $M=96.7)$, and Truitt's (1995) study of Korean EFL students $(M=101.2)$. The mean was only slightly higher than that of Turkish-speaking EFL learners in Kunt's (1997) study ( $M=89.4$ and $M=90.8)$. The results indicate that Chinese university first-year English majors are less anxious about learning English in the context of the English classroom compared with students in several other studies, but they showed a little more anxiety than the Turkish EFL students.

In terms of the relationship between Chinese university first-year English majors' beliefs and foreign language learning anxiety, the results were really far from conclusive. Two belief factors were significantly correlated with foreign language anxiety. One of the relationships was negative (Factor 2 and anxiety) and the other one was positive (Factor 3 and anxiety). The results seemed to indicate that the stronger the students' beliefs in self-efficacy and confidence, the less anxious they were. However, those students who believed learning English well should be through formal and structured learning seemed to be more anxious than students who did not have such beliefs. For the beliefs items, five items were significantly correlated with anxiety. Items 26,16 and 1 had negative relationships with anxiety, while items 14 and 17 had positive relationships with anxiety. Items 26 and 16 seemed to have the strongest negative correlations with anxiety relative to other items, which indicated that students who believe it is possible for them not to get nervous when speaking English and who are satisfied with their progress in English tend to have less foreign language learning anxiety than their peers without such beliefs. Here it was interesting to find that students who believe that they should not be forced to speak in the English class and who prefer their English teachers to explain important things in their first language in order for them to understand everything tend to be more anxious than those students who do not have such beliefs.

On the whole, the correlation coefficients between either factors or items and foreign language anxiety were quite small $(\mathrm{r}<0.30)$. In the multiple regression models, both the factor model and the item model could only account for a small amount of variance of foreign language anxiety. All the signs point to a very weak relationship between learner beliefs and foreign language learning anxiety. The weak relationship may be attributed to the relatively small sample size in this study, as Oh (1996) suggested. 


\subsection{Limitations and Suggestions for Future Research}

This study has some limitations. The sample size in this study is relatively small $(\mathrm{N}=151)$. Hence, a larger sample size is suggested for further studies. Also, the data eliciting instruments utilised in this study were self-report questionnaires. Other data collection methods could be used in order to gain different perspectives on the phenomena examined in this study. Finally, the choice of subjects for this study was limited to first-year university students who were English majors, which may limit the generalisability of the results of this study. Therefore, students at different stages in their education and those learning English while majoring in other subjects could be involved in further studies.

\section{References}

Aida, Y. (1994). Examination of Horwitz, Horwitz, and Cope's construct of foreign language anxiety: The case of students of Japanese. Modern Language Journal, 78, 155-68.

Albright, J.J. \& Park, H.M. (2009).Confirmatory Factor Analysis using Amos, LISREL Mplus, SAS/STAT CALIS*. Retrieved 10 September 2011

http://www.indiana.edu/ statmath/stat/all/cfa/cfa.pdf

Alpert, R. \& Haper, R. (1960). Anxiety in academic achievement situations. Journal of Abnormal and Social Psychology, 61, 207-215.

Ajzen, I. (1985). From intentions to actions: A theory of planned behaviour. In J. Kuhl \& J. Beckmann (Eds.) Action control: From Cognition to Behaviour (pp.11-39). Berlin: Springer-Verlag.

Ajzen, I. (1988). Attitudes, Personality, and Behaviour. Buckingham UK: Open University Press.

Ajzen, I. (1991). The theory of planned behaviour. Organisational Behavior and Human Processes, 50 (2), $179-211$.

Ajzen, I. (1996). The directive influence of attitudes on behaviour. In P.M. Gollwitzer \& J.A. Bargh (Eds.), The Psychology of action: Linking cognition and motivation to behavior (pp.385-403). New York: Guilford Press.

Ajzen, I. (2002). Contructing a TpB questionnaire: Conceptual and methodological considerations. Retrieved 13 September 2011:

http://socgeo.ruhosting.nl/html/files/spatbeh/tpb.measurement.pdf

Ballard, B. and Clanchy, J. (1991) Teaching Students from Overseas: A Brief Guide for Lecturers and Supervisors. Melbourne: Longman Cheshire.

Bandura, A. (1986). The exploratory and predictive scope of self-efficacy theory. Journal of Social and Clinical Psychology, 4, 359-373.

Benson, P. \& Lor, W. (1999). Conception of language and language learning. System, 27(4), 459-472.

Brown, H.D. (1987). Principles of Language Learning and Teaching. Englewood Cliffs, NJ: Prentice-Hall.

Clément, R. \& Gardner, R.C. (2001). Second language mastery. In H. Giles \& W.P. Robinson (Eds.), The New Handbook of Language and Social Psychology (2 ${ }^{\text {nd }}$ ed.). London: Wiley.

Cohen, J. (1988). Statistical Power Analysis for the Behavioral Sciences (second ed.). Lawrence Erlbaum Associates.

Cohen, J. et al. (2003). Applied Multiple Regression/Correlation Analysis for the Behavioral Sciences ( ${ }^{\text {rd }}$ Edition). New Jersey: Lawrence Erlbaum Associates.

DeVellis, R.F. (1991), Scale Development, Theory and Applications. London: Sage.

Dycus, D. (1997). Guessing word meaning from context: Should we encourage it? Literacy Across Culture, 1(2),1-2.

Gardner, R.C. \& Lambert, W.E. (1959). Motivational variables in second language acquisition. Canadian Journal of Psychology. 13, 266-72.

Gardner, R.C. \& Santos, E. (1970). Motivational variables in second language acquisition: A Philippine investigation. Research Bulletin, No. 149. University of Western Ontario.

Horwitz, E.K. (1986). Preliminary evidence for the reliability and validity of a foreign language anxiety scale. TESOL Quarterly, 20, 559-562.

Horwitz, E.K. (1987). Surveying student beliefs about language learning. In A.L. Wenden \& J. Rubin (Eds.),Learner Strategies in Language Learning (pp. 119-29). Hemel Hempstead: Prentice Hall.

Horwitz, E.K. (1988). The beliefs about language learning of beginning university foreign language students. Modern Language Journal, 72(iii), 283-294.

Horwitz, E.K. (1989). Recent research on second language learners: Beliefs and anxiety. Texas Papers on Foreign Language Education, Special Edition.

Horwitz, E.K., Horwitz, M.B. \& Cope, J. (1986). Foreign language classroom anxiety. The Modern Language Journal, 70, 125-32.

Horwitz, E.K., Horwitz, M.B. \& Cope, J. (1991) Foreign language classroom anxiety. In E.K. Horwitz and D.J.Young (Eds.), Language Anxiety: From Theory and Research to Classroom Implications (pp. 27-36).Englewood Cliffs, NJ: 


\section{Prentice Hall.}

Kunt, N. (1997). Anxiety and beliefs about language learning: A study of Turkish-speaking university students learning English in North Cyprus. Unpublished doctoral dissertation. University of Texas, Austin.

Le, J.Y. (2005). Affective characteristics of American students studying Chinese in China: A study of heritage and nonheritage learners' beliefs and language anxiety. Unpublished doctoral dissertation. University of Texas, Austin.

MacIntyre, P.D. and Gardner, R.C. (1991). Anxiety and second language learning: toward a theoretical clarification. In E.K. Horwitz and D.J. Young (Eds.), Language Anxiety:From Theory and Research to Classroom Implications. New Jersey: Prentice Hall.

Oh, J. (1990). On the relationship between language anxiety and reading English as a foreign language among Korean university students in Korea. Unpublished doctoral dissertation University of Texas, Austin.

Oh, M.-J. T. (1996). Beliefs about language learning and foreign language anxiety: A study of American university students learning Japanese. Unpublished doctoral dissertation, University of Texas, Austin.

Park, G. (1995). Language learning strategies and beliefs about language learning of university students learning English in Korea. Unpublished doctoral thesis. University of Texas, Austin.

Philips, E. (1990). The effects of anxiety on performance and achievement in an oral test of French. Unpublished doctoral thesis. University of Texas, Austin.

Sakui, K., \& Gaies, S. (1999). Investigating Japanese learners’ beliefs about language learning. System, 27, 473-492.

Scovel, T. (1978). The effect of affect: A review of the anxiety literature. Language Learning, 28, 129 -142.

Spielberger, C.D. (1983). Manual for the State-Trait Anxiety Inventory. Palo Alto, CA: Consulting Psychologists Press.

Spolsky, B. (1989). Conditions for Second Language Learning. Oxford: Oxford University Press.

Tanaka, K. (2004). Changes in Japanese students' beliefs about language learning and English language proficiency in a study-abroad context. Unpublished doctoral thesis. University of Auckland, New Zealand.

Truitt, S.N. (1995). Anxiety and beliefs about language learning: A study of Korean university students learning English. Unpublished doctoral dissertation. The University of Texas, Austin.

Tudor, I. (2001). The Dynamics of the Language Classroom. Cambridge: Cambridge University Press.

Wen, Q. \& Johnson, R. (1997). L2 learner variables and English achievement: A study of tertiary-level English majors in China. Applied Linguistics, 18(1), 27-48.

Wenden, A. (1986). What do second language learners know about their language learning? A second look at retrospective accounts. Applied Linguistics, 7, 186-201.

Wenden, A. (1987). How to be a successful learner: Insights and prescriptions from L2 learners. In A. Wenden and J. Rubin (Eds.), Learner Strategies in Language Learning (pp. 103-117). Englewood Cliffs, N.J.: Prentice Hall.

Yang, N. (1992). Second language learners' beliefs about language learning and their use of learning strategies: A study of college students of English in Taiwan. Unpublished doctoral dissertation. University of Texas, Austin.

Young, D.J. (1986). The relationship between anxiety and foreign language oral proficiency ratings. Foreign Language Annals, 19 (5), 439-445.

Young, D.J. (1991). Creating a low-anxiety classroom environment: What does language anxiety research suggest? Modern Language Journal, 75 (4), 426-439.

\section{Appendix A}

\section{Questionnaire A}

I would like to invite you to help me by answering the following questions concerning your beliefs about English learning. Your answers will be collected, analysed and used in my research. This is not a test, so there are no "right" or "wrong" answers. I'm interested in your personal experience and opinion. Please give your answers sincerely as only this will guarantee the success of the investigation. Thank you very much for your help!

Name: (Your name will not be shown in any published papers)

\section{Questions Related to Learning English}

In this questionnaire, you will find a total of 27 statements related to learning English. After reading each statement, circle the response 1 (strongly disagree), 2 (disagree), 3 (neutral, neither agree nor disagree), 4 (agree), or 5 (strongly agree) that tells to what extent you agree or disagree with the statement. 
Strongly agree $=5$, Agree $=4$, Neutral $=3$, Disagree $=2$, Strongly disagree $=1$

1. I can learn well by speaking with others in English. 54321

2. If I am permitted to make mistakes in English, $\quad 54321$ it will be difficult for me to speak correctly later on.

3. I can learn well if I try to study English outside class on my own.

4. I can learn English well by writing down everything in my notebook.

5. In order to speak English well, it is important for $\quad 54321$ me to learn grammar.

6. It doesn't matter if I make mistakes when speaking with others in English.

7. In order to learn well, it is important for me to review what I have been taught in the English class.

Strongly agree $=5$, Agree $=4$, Neutral $=3$, Disagree $=2$, Strongly disagree $=1$

8. I should be able to understand everything I read in English.

9. In order to learn well, it is important for me to try to think about my progress in English.

10. I can learn well by listening to the radio or watching 54321 TV in English.

11. Memorisation is a good way for me to learn English.

12. I can learn English well by living in an Englishspeaking country (e.g. New Zealand).

13. I can learn English well by following a textbook.

14. I should not be forced to speak in the English class.

54321

15 I can learn English well if I am studying just for

54321 pleasure.

16. I am satisfied with my progress in English so far.

17. I would like my English teacher to explain important things in my first language so I can understand everything.

18. I can learn English well in a class where the teacher maintains good discipline.

19. I can learn well by using English outside class.

20. I should be able to understand everything the teacher says in the English class.

21. It's okay to guess if I do not know a word in English.

22. I can learn well by reading English magazines or newspapers.

23. It is possible for me to learn to speak English very well.

24. I can learn well if I try to think in English.

54321

54321

54321

54321

54321

54321

Strongly agree $=5$, Agree $=4$, Neutral $=3$, Disagree $=2$, Strongly disagree $=1$

25. In order to speak English well, it is important for 54321 me to learn vocabulary.

26. It is possible for me not to get nervous when speaking English.

27. I would like my English teacher to correct all my mistakes. 
附录 A（Beliefs Questionnaire Chinese Version）

调查问卷

我想邀请您回答一些您学习英语过程中矢于学习信念方面的问题。我将对您的回答进行分析, 并把它们用于我 的博士论文中。这不是一项测试, 没有正确和错误答案之分。我对您的学习经历和个人观点非常感兴趣。因此 , 您只需要诚实地回答以下问题。您的回答将决定该研究的成功与否。

非常感谢您的帮助和合作！

姓名: (您的名字不会显示在任何发表的文章中)

本部分包含了 27 个陈述性问题。每读完一个问题后，请在 1 (很不同意 ),2（不同意），3（不确定），4（同 意 ），5（很同意 ）中选择一个符合您对该陈述认可程度的选项。

$1=$ 很不同意 $2=$ 不同意 $3=$ 不确定 ( 既不同意也不反对 ） $4=$ 同意 $5=$ 很同意

1. 通过与别人用英语交谈，我能学好英语。12345

2. 如果允许我在使用英语时犯错误，之后我将很难准确地说好英语。1 2345

3. 如果我试图自己在课外学习英语的话，我能学好英语。1 2345

4. 通过把所有的东西都写在笔记本上，我能学好英语。1 23445

5. 想说好英语，学习语法对我来讲很重要。1 2345

6. 当我与别人说英语的时候犯些错误是没什么矢系的。1 2345

7. 想学好英语，回顾在英语课上被教授的知识对我来讲很重要。1 23445

8. 我应该有能力理解所有我在英语中读到的东西。1 2345

9. 想学好英语，试着想想我在英语中的进步对我来说很重要。1 23445

10. 通过听广播和看电视，我能学好英语。1 2345

11. 记忆对我学习英语是个好方法。1 2345

12. 通过在国外生活，我能学好英语。1 2345

13. 通过认真学习一本教科书，我能学好英语。1 2345

14. 我不应该被强迫在英语课堂上说英语。1 2345

15. 如果我仅仅是因为乐趣而学习英语，我能学好英语。1 12345

16. 到目前为止，我对我英语上的进步感觉很满意。1 2345

17. 我想让英语老师用我的母语解释重要的东西以便我能明白所有的东西。12345

18. 在老师能维持好纪律的课堂上，我能学好英语。1 2345

19. 通过在课外使用英语，我能学好英语。1 2345

20. 我应该能明白老师在英语课堂上说的所有东西。1 2345

21. 如果我不知道一个英语单词，猜测是不错的方法。1 2345

22. 通过阅读英语杂志和报纸，我能学好英语。1 2345

23. 我有可能说一口流利的英语。1 2345

24. 如果我试着用英语思维，我能学好英语。1 23445

25. 想学好英语，学习词汇对我来讲很重要。1 20345

26. 在说英语的时候步紧张对我老说事有可能性的。1 2345

27. 我想让英语老师纠正我所有的错误。1 2345

再次感谢您的合作 !

\section{Appendix B \\ Questionnaire B}

I would like to invite you to help me by answering the following questions concerning your reasons for learning English. Your answers will be collected, analysed and used in my research. This is not a test, so there are no "right" or "wrong" answers. I'm interested in your personal experience and opinion. Please give your answers sincerely as only this will guarantee the success of the investigation. Thank you very much for your help!

Name: (Your name will not be shown in any published papers)

\section{Questions Related to English Learning}

In this section, you will find a total of 30 statements related to English learning. After reading each statement, circle the response 1 (strongly disagree), 2(disagree), 3(neutral, namely neither agree nor disagree), 4(agree) or 5(strongly agree) that tells to what extent you agree or disagree with the statement. 
Strongly agree $=5 \quad$ Agree $=4 \quad$ Neutral $=3 \quad$ Disagree $=2 \quad$ Strongly disagree $=1$

1. I fell in love with English at first sight, without particular reasons.

2. I began to study English because my parents/ school required me to learn it.

3. Before entering university, my purpose in learning English was mainly to obtain high scores in the university entrance examination.

4. Before entering university, my effort at English learning depended to a large extent on test scores.

5. Before entering university, my effort at English learning depended to a large extent on whether I liked my English teacher or not.

6. After entering university, my effort at English learning depended to a large extent on test scores.

7. After entering university, my effort at English learning depended to a large extent on whether I like my English teacher or not

8. After entering university, my effort at English learning depended to a large extent on the quality of English classes.

9. After entering university, my effort at English learning depended to a large extent on the quality of English textbooks.
54321

54321

54321

54321

Strongly agree $=5 \quad$ Agree $=4 \quad$ Neutral $=3 \quad$ Disagree $=2 \quad$ Strongly disagree $=1$

10. After entering university, my effort at English learning depended to a large extent on whether I like the fellow students in the English class.

11. An important purpose for my English learning is to obtain a university degree.

12. The direct objective of my English learning is to obtain high scores in examinations for the purpose of going abroad or career development in China.

13. Learning English is very important for me, because English is a very useful tool in contemporary society.

14. Learning English can give me a sense of achievement.

15. I learn English in order to facilitate other academic subjects.

16. Only with good English skills can I find a good job in the future.

17. I learn English so as to catch up with economic and technological developments in the world.

18. I learn English because I am interested in English speaking peoples and their cultures.

19. I have a special interest in language learning.

20. Out of my love of English songs/movies, I have developed a great interest in the language.

21. I learn English just because I like this language.

22. I learn English in order to let the world know more about China.

23. Out of my love of English literature, I have developed a great interest in the language.

24. Only when I have good command of English can I contribute well to China's prosperity.
54321

54321 
Strongly agree $=5 \quad$ Agree $=4 \quad$ Neutral $=3 \quad$ Disagree $=2 \quad$ Strongly disagree $=1$

25. Only when I have good command of English can I live up to the expectations of my parents.

26. I learn English in order to find better education and job opportunities abroad.

27. I learn English so that I can go abroad to experience English-speaking cultures.

28. The ultimate purpose of my English learning is to live permanently in English-speaking countries.

29. Acquiring good English skills is a stepping-stone to one's success in life.

30. Fluent oral English is a symbol of good education and accomplishment.
54321

54321

54321

54321

54321

54321

The End

Thank you again for your help and cooperation!

附录B：( FLCAS Chinese Version )

我邀请您回答一些关于您学习英语原因方面的问题。我的博士论文将使用并分析您的回答。这不是一项测试, 没有正确和错误答案之分。我对您的学习经历和个人观点非常感兴趣。因此, 您只需要诚实地回答以下问题。 您的回答将决定该研究的成功与否。

\section{非常感谢您的帮助和合作！}

姓名: (您的名字不会显示在任何公开发表的文章中)

本部分包含了 30个陈述性问题。每读完一个问题后，请在1（很不同意），2（不同意），3（不确定），4（同 意 ），5 ( 很同意 ) 中选择一个符合您对该陈述认可程度选项。

1= 很不同意 $2=$ 不同意 $3=$ 不确定 ( 既不同意也不反对 ） $4=$ 同意 $5=$ 很同意

1. 我对英语一见钟情，说不出有什么特别的原因。1 23345

2. 我开始学英语是因为父母/学校要我学。12345

3. 上大学前学习英语，主要是为了升学考试。1 12345

4. 上大学前，我学英语的劲头很大程度上取决于我的学习成绩。 12345

5. 上大学前，我学英语的劲头很大程度上取决于是否喜欢英语老师。 122345

6. 上大学后，我学英语的劲头很大程度上取决于我的学习成绩。 1223445

7. 上大学后，我学英语的劲头很大程度上取决于是否喜欢英语老师。 122345

8. 上大学后，我学英语的劲头很大程度上取决于英语课的质量。 123345

9. 上大学后，我学英语的劲头很大程度上取决于所用的教材。1 12345

10. 上大学后，我学英语的劲头很大程度上取决于是否喜欢我的英语班。1 2345

11. 我学英语的一个重要目的是获取大学毕业证书。12345

12. 我学英语的直接目的是在出国或国内升学、求职考试中取得好成绩。1 2345

13. 学好英语对我很重要，因为它是当今社会非常有用的交流工具。 12345

14. 学好英语能让我获得成就感。1 2345

15. 我学习英语，是为了更好地学习其他专业。1 12345

16. 学好英语，将来我才可能找到一份好工作。 123345

17. 我学习英语是为了了解世界各国的经济、科技发展情况。1 12345

18. 我学习英语是因为对英语国家的人以及他们的文化感兴趣。 12345

19. 我对语言学习有特别的爱好。1 2345

20. 对英语歌曲/电影的爱好使我对英语产生了很大兴趣。1 12345

21. 我学习英语是因为我喜欢这门语言本身。 123345

22. 我学习英语是为了让世界了解中国。1 123445

23. 对英语文学作品的爱好使我对英语产生了很大兴趣。 123345

24. 学好英语，我才能很好地为中国的富强尽力。 12345

25. 学好英语，我才能不幸负父母的期望。12345

26. 我学习英语是为了出国寻找更好的受教育和工作机会。1 12345

27. 我学习英语是为了出国亲身体验英语国家的文化。1 2345

28. 我学习英语是为了最终移民外国。1 2345

29. 英语是人生前进路上一块重要的敲门砖。 12345

30. 讲一口流利的英语，是教育程度和修养的象征。 122345 


\section{Appendix C}

Principal Component Analysis and Scree Plot

Table: Promax Rotated Component Matrix

\begin{tabular}{|c|c|c|c|c|c|c|c|c|c|c|}
\hline Component & Eigenvalues & \multicolumn{5}{|c|}{$\%$ of Variance } & \multicolumn{4}{|c|}{ Cumulative \% } \\
\hline 1 & 4.903 & \multicolumn{5}{|c|}{18.159} & \multicolumn{4}{|c|}{18.159} \\
\hline 2 & 2.538 & \multicolumn{5}{|c|}{9.401} & \multicolumn{4}{|c|}{27.569} \\
\hline 3 & 1.949 & \multicolumn{5}{|c|}{7.217} & \multicolumn{4}{|c|}{34.777} \\
\hline 4 & 1.604 & \multicolumn{5}{|c|}{5.941} & \multicolumn{4}{|c|}{40.718} \\
\hline 5 & 1.509 & \multicolumn{5}{|c|}{5.589} & \multicolumn{4}{|c|}{46.307} \\
\hline 6 & 1.317 & \multicolumn{5}{|c|}{4.876} & \multicolumn{4}{|c|}{51.183} \\
\hline 7 & 1.251 & \multicolumn{5}{|c|}{4.632} & \multicolumn{4}{|c|}{55.815} \\
\hline 8 & 1.074 & \multicolumn{5}{|c|}{3.987} & \multicolumn{4}{|c|}{59.794} \\
\hline 9 & 1.021 & \multicolumn{5}{|c|}{3.780} & \multicolumn{4}{|c|}{63.574} \\
\hline & & 1 & 2 & 3 & 4 & 5 & 6 & 7 & 8 & 9 \\
\hline & Item1 & .129 & .337 & .067 & .224 & -.187 & .483 & -.237 & .092 & .296 \\
\hline & Item2 & -.018 & .009 & .163 & .171 & .016 & .037 & -.056 & .021 & -.840 \\
\hline & Item3 & .231 & .375 & .075 & .100 & .119 & .424 & -.402 & .021 & -.144 \\
\hline & Item4 & -.002 & -.055 & .794 & .008 & .040 & .074 & -.026 & .157 & -.081 \\
\hline & Item5 & -.085 & .173 & .220 & -.683 & .046 & -.025 & .191 & .149 & .051 \\
\hline & Item6 & .004 & -.009 & .213 & .285 & .028 & -.034 & -.276 & .033 & .600 \\
\hline & Item7 & -.010 & .226 & .385 & -.229 & .031 & .555 & .466 & -.118 & .029 \\
\hline & Item8 & .603 & .228 & .263 & -.074 & .196 & .048 & -.013 & -.200 & .074 \\
\hline & Item9 & .137 & .068 & -.019 & -.061 & .081 & .801 & .096 & .210 & -.108 \\
\hline & Item10 & .078 & .810 & .140 & .050 & .047 & .026 & -.041 & .030 & -.066 \\
\hline & Item11 & .006 & .231 & .261 & -.182 & .172 & .218 & .019 & .633 & .002 \\
\hline & Item12 & .045 & .118 & .216 & .458 & -.140 & .125 & .114 & .564 & .162 \\
\hline & Item13 & .090 & .295 & .581 & .013 & .310 & .000 & .317 & .090 & .127 \\
\hline & Item14 & .064 & $\begin{array}{l}.006 \\
\end{array}$ & .242 & .106 & .575 & -.176 & -.175 & .027 & .069 \\
\hline & Item15 & .047 & .155 & .124 & .799 & .177 & $\begin{array}{l}.083 \\
\end{array}$ & .164 & $\begin{array}{l}-.013 \\
\end{array}$ & .009 \\
\hline & Item16 & .304 & .387 & .240 & .105 & .099 & -.022 & -.317 & -.409 & -.035 \\
\hline & Item17 & -.219 & -.152 & -.017 & .009 & .744 & .171 & .008 & -.064 & -.073 \\
\hline & Item18 & .049 & .187 & .027 & -.007 & .658 & .044 & .343 & .119 & -.008 \\
\hline & Item19 & .143 & .682 & -.123 & .003 & .053 & .062 & .037 & .283 & .140 \\
\hline & Item20 & .754 & .055 & .182 & -.027 & -.042 & $\begin{array}{l}.004 \\
\end{array}$ & $\begin{array}{l}.078 \\
\end{array}$ & -.036 & -.031 \\
\hline & Item21 & .587 & .244 & -.104 & .198 & -.082 & .197 & .046 & -.039 & .163 \\
\hline & Item22 & .179 & .716 & .018 & -.099 & -.130 & .178 & .178 & -.029 & -.059 \\
\hline & Item23 & .763 & .049 & -.078 & .061 & -.089 & .067 & .048 & .187 & -.069 \\
\hline & Item24 & .348 & .470 & -.030 & .080 & -.262 & .298 & .103 & .226 & .057 \\
\hline & Item 25 & .487 & .150 & .020 & -.199 & .055 & .025 & -.117 & .554 & -.189 \\
\hline & Item26 & .594 & .121 & -.347 & .148 & -.060 & .073 & .230 & .143 & .055 \\
\hline & Item27 & .100 & .071 & .057 & .068 & .079 & .057 & .772 & .049 & -.129 \\
\hline
\end{tabular}

Sere日 Plot



Figure: Scree Plot of Nine Components 